\title{
94 maids, machines and morality in Brazilian homes
}

\author{
Elizabeth Silva
}

\section{abstract}

This paper engages with debates about the increasing use of paid domestic labour in Europe and the USA, contributing with a reflection about the case of Brazil. Relations of gender, class and race are considered in the deployment of maids for housework, the patterns of consumption of household technologies and the moral reasoning of daily living with hierarchical divisions within the home. The paper considers some parallels between the Brazilian context and that of more developed countries and also the specificity of Brazil. Based on participant observation, secondary data and an ethnographic study, rich empirical data is weaved through to discuss material and moral dimensions of domestic labour and care. How does the availability of cheap domestic labour configure relations of inequality? How are social differences in the home lived with and justified? The exploration of the Brazilian case illuminates some of the problems, contradictions and possible consequences of wealthier households benefitting from the displacement of poor women that is currently happening through international migration. The paper argues that in Brazil the deflecting of tensions in gender divisions of labour in households onto a subordinate person has affected relations of equality between women and men and also the patterns of technological innovation to facilitate housework. These are outcomes to be guarded against in Europe and the United States in face of the current trends in 'global woman' relations.

\section{keywords}

maids; household technologies; morality; Brazil; domestic labour; gender divisions 


\section{introduction}

Technological innovations have changed domestic work dramatically since the beginning of the twentieth century in every country and context where these modern shifts applied. These have happened in tandem with changes in the position of women in society affecting relationships between women of different social classes and between women and men. These concerns are topical in view of discussions about migration movement of women informing current globalization debates. These movements have been partly fuelled by the employment by better off households in richer countries of women domestic workers from poorer countries. In Brazil, wealthy homes have always had large amounts of cheap domestic labour available to 'import' from poorer areas. How is this practice configured in relations of inequality in the country? What effect does it have on household technologies consumption? How are deeply entrenched social differences in the home lived with on a daily basis and justified? The exploration of these issues in this paper aims to contribute to further reflection about the 'global woman' debate.

Bridget Anderson's (2000) study of the politics of domestic labour in contemporary Europe shows the predominance of racialized groups in paid work in the home and calls attention to the pernicious effects this employment has on relations between middle-class women and men who thus avoid both conflicts and challenges to their entrenched gendered positions of inequality. Anderson's perceptive study points to the gender and generational conflicts implicated in the employment of a person to do domestic tasks. She argues that the employment of paid work in the home creates particular sorts of relationships developing personhood, not just as a worker but also as an employer, and entails particular sets of gender relations. Central to the construction of personhood is the consumption of care in the buying and selling relation. Anderson argues, following Arlie Hochschild (1997), that as women flee from the home into outside employment no one is left to care. The 'new' domestic workers thus fill this gap. Yet, while the argument for the centrality of the need of 'buying love' in the new domestic labour contracts is important, the material dimensions of this work, which remain arduous and lengthy, need to be kept in focus. There are many reasons for considering the emotional and the material dimensions together. One relates to how they both link with unequal relationships predicated on positions of class, gender and race. Another refers to cultural needs of material and emotional care, demanded within particular 'moral' environments justifying particular patterns of relationships in domestic life. One other salient reason refers to concrete material conditions related to demands of contemporary lifestyles. In this paper I focus specifically on the reasons I call 'ordinary morality', and on how housework technologies are deployed, as part of the materiality of ways of living. These are explored within the specific configuration of relationships of class, gender and race prevailing in Brazil. 
I argue that a major implication of the widespread use of paid domestic work is to hinder technological developments for housework. This crucial political outcome has been neglected in feminist debates about domestic labour. Women and homes remain marginal to technological innovation concerns (Silva, 2002). The cost of women's domestic labour is central to these developments. While technological modernization in machines for housework is globally uneven as different levels of availability of domestic workers play a significant role in the differentiated patterns of innovation across regions. Yet, domestic labour availability is not simply a numerical concern. The ways in which the social relations implicated in its deployment are justified constitute the moral context enabling its use as resource for the social position of those able to pay. The material and the moral are interlinked.

On the basis of participant observation, secondary data and a case study in the south of Brazil I discuss maids, machines and moralities in households. The ethnographic study was carried out in 1997 in the southeast of Brazil, in the affluent region of Greater Campinas, in the State of São Paulo. The study centres on the differences between poor and middle-class homes regarding women's work and the gendered domestic divisions of labour, with a particular concern with how paid domestic work affects the division of labour in households and the consumption of household technologies (Silva, 1998). There was no intention to produce a representative sample of the population in statistical terms. But 1 wished to capture the relationships of women and men with domestic labour, and I wanted to include a wide range of social experiences of this kind. Families were selected according to their significance for theory, ideas and concepts. I carried out participant observation and 55 semi-structured interviews ( 30 women and 25 men) in 30 families. All families had dependent children, 22 of them included children of school age (5-16). Women defined themselves as 'housewives' in nine households. Twenty-one families self-classified as white.

The Brazilian case has some parallels with those in more developed countries. For instance, in Britain the growth of female employment, particularly that of married women, has, like in Brazil, been sharp since the 1970s. In a longer historical trend, UK consumption of technologies for the home grew enormously in the 1930s when domestic servants were fast disappearing (Glucksmann, 1990). But does the Brazilian trend reflect a process towards greater equality between women and men, and among women, broadly similar to those in developed countries? How have women's jobs outside the home affected the patterns of domestic living? What has happened in Brazilian homes when women have in growing numbers taken on outside employment? As paid domestic labour becomes an increasingly significant feature of middle-class home life in contemporary Europe and North America (Ehrenreich and Hochschild, 2002; EJWS, 2007) through processes of the displacement of the poorer women across the globe, an exploration of the Brazilian case is illuminating. Contradictions of 
economic development within Brazil have resulted in great disparities of wealth that somewhat mirror the patterns of inequality in the context of home life of the international contexts involved in the domestic work world exchanges on a global scale. Brazilian specificities also remain.

\section{maids}

In Rio de Janeiro, in the southeast of Brazil, Maria, the maid, stepped out of the kitchen at lpm bringing food to the table. Ronaldo, Anita, and their children, Fernando (13) and Manuela (16), sat around it. So did I, as a friend of Anita. We had a salad for starter, four hot dishes to choose from, two desserts, and cold and hot drinks. It was a normal weekday. When the meal was finished, everyone moved on to their personal affairs and the table was left for Maria to clear. Maria lived in a small bedroom in a secluded part of the house adjacent to the kitchen. This was the 'service area' where laundry, ironing and cooking was done, hidden away. Maria was only seen when she served water, coffee, at meal times, or while she quietly and unobtrusively made the beds, mopped the floors, and cleaned the bathrooms in the morning. Maria was up before $7 \mathrm{am}$ to serve breakfast, and she was still up at $9 \mathrm{pm}$ clearing the table after dinner. Maria came from the Northeast and had been working for Anita for about 10 years. Anita relied on Maria for all the housework. Anita was an academic, like me. She worked on poverty and land reform in the Northeast. She would never consider her everyday life without ' $a$ ' Maria. She did not engage with my attempts to converse about servants and their social inequalities. Anita was Brazilian. All the people in this scenario are white.

In Recife, in the northeast of Brazil, Vanya went shopping with Janice, her cook. Janice pushed the trolley, picked up the goods, and placed bags in the car. Vanya told Janice what to buy, paid and drove the car. At home Janice removed bags from the car and put the goods away. The living-in nanny, Teresa, looked after five-year-old Julian, keeping him out of the way so that Cida, the cleaner, could get on with her jobs. I was a friend of Vanya, staying for a few days. I could not even make myself a cup of tea or get a glass of water from the kitchen. Whenever I stepped in through the door a servant offered to attend to my needs. Vanya was an academic, like me, working on sexuality and 'race'. She could not imagine a life of looking after children, doing housework, relating to a partner and researching in 'culture' without ' $a$ ' Janice, 'a' Teresa and ' $a$ ' Cida. Vanya was English. Everyone in this scenario is black except for my friend and $I$.

These are two stories of people with widely varying cultures and social positions. All were immersed in a world of deep social inequality. Anita alone earned 10

times more than she paid Maria. Maria worked very long hours, had no pension, house or security. They were the same age. Vanya paid her three servants 
together in Recife as much as Anita paid Maria alone in Rio. This was why Northeastern Maria was grateful to have her Rio job. Both Anita and Vanya had husbands who earned quite a lot more than they did. The income of each one of the families was about 40 times higher than their servants' wages. The husbands were seen by Anita and Vanya as sensitive men, good providers and supporters. They did no housework or childcare. But then ... even I could not get myself a glass of water without having it offered to me on a tray!

Why was it so easy for my well-off friends to live a 'comfortable' life with such social inequalities crying out from within their homes? The ease of access to the labour of others obviously derived from economic inequalities. But the moral issues also appeared significant. How was this seen as a 'proper' way of running homes? What political consequences did it have for wider economic and social contexts? Moreover, how could these practices coexist with contemporary transformations of women's positions in the labour market and in society?

One of the most significant changes in Brazil since the 1970s has been the increasing participation of women in the labour market. This is linked to economic necessities and employment demands, but also to demographic and cultural changes like a reduced fertility rate and increased education. Already in 1995, 40 per cent of the Brazilian workforce was female. This rate was 45 per cent in the more developed São Paulo Metropolitan Region in 2001 (SEADE, 2002). In 2005, 53 per cent of women were in the economically active population (Fundaçáo Instituto Brasi Peiro de Geografia e Estatística (FIBGE) in Bruschini, 2007, Table 1). The increase has been greater in urban areas and in the most developed regions. Married, co-habiting and separated (including divorced) women have played a bigger part in the employment rise than single women. The proportion of married women working has been more than half since 1993 Pesquisa National por Amostra de Domicílios (PNAD). Ethnicity has strongly shaped the place of women in the employment structure. A recent study by the International Labour Organization, based on data from Brazilian national statistics (PNAD, 2001), shows that the difference between black and white women employed as 'domestics' is large: 24 per cent of blacks against 14 per cent of whites (ILO, 2005: 3). Yet, the proportion of all women employed in domestic labour has decreased, particularly in the more developed urban areas, where this kind of employment has been more prominent (Bruschini, 2000, 2007). In a related development, the consumption of technologies for housework has grown since the 1960s (Toledo, 1989; Neto, 1992; Abinee, 1994, 2005; Gitahy et al., 1997). The consumption of these technologies relates to increased purchasing power, lower prices of goods, changes towards smaller family units and also to different ways of dealing with housework demands.

In terms of levels of wealth, colour of skin and employment of domestic labour, the households in my study show a striking picture of inequality and subordination in the home. Skin colour grows whiter as the income level 
Table 1 Income, ethnicity and paid domestic help

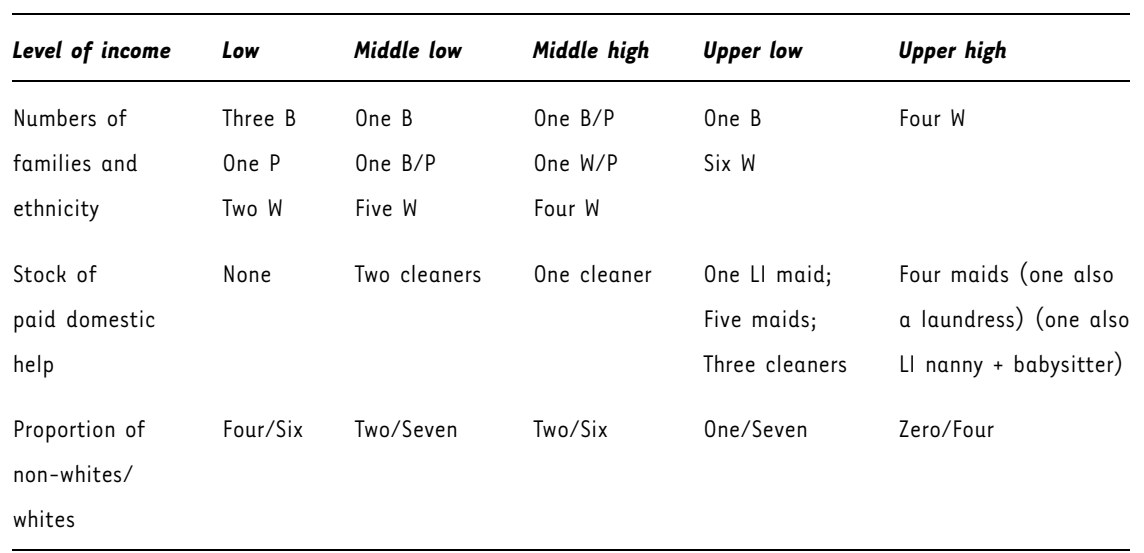

Abbreviations: $\mathrm{LI}=$ Living in; $\mathrm{B}=\mathrm{Black}$; $\mathrm{P}=$ Pardo (skin colour designating mixed black and white); $W=$ White.

increases. The employment of paid domestic help increases with income and the whiteness of the skin. Table 1 indicates that the place of individuals in society and their access to the labour of others appears firmly based on income class. The proportion of families in each level of income in this study is far from being statistically representative. There is a deliberate larger intake of higher incomes because of a concern with the effects of paid domestic service on the gender division of labour and on inequalities in the home. For Brazil as a whole at the time of my study, more than 50 per cent of the population earned below two minimum wages (only one of the families studied had this low income), with just 5 per cent earning more than 10 minimum wages (24 of the families in this study earned more than 10 minimum wage equivalents). The region investigated is one of the most affluent in Brazil, with a population affording much higher incomes than for the country as a whole. Thus, it is to be expected that a statistical representation of these variables would show a staggering disparity of what is qualitatively represented here. I indicate five income categories to grasp the gradient of very high wealth disparity. All the paid domestic workers were females.

The majority of women (21) in these households had employment outside of the home. Seven had no earnings and two earned only very small amounts, one from child minding and another from architectural design. All of them were mothers of small children and five of them were lone mothers. They mostly had busy daily schedules. Women contributed half or more of the household income in over onethird of the families. There were only four women who were sole household earners (two of them were lone mothers), and they were all in the low-income group. Three of the women in the low-income group worked as maids in wealthier households. These were the only three maids included, in their home contexts, in 
this study. ${ }^{1}$ The women's income was absolutely significant for the economy of their households when in the low-income group, but it was also important in the middle-high and upper-low income households. Despite this, the woman's income did not change her status in the home in any significant way. This is confirmed by Cynthia Sarti's (1996) study of poor families in São Paulo that argues that the distribution of 'authority' in the family was based on the different, and traditional, roles of men and women.

However, in the families I studied, it was often the woman's income that objectively positioned the household in a higher income category. It was only in the middle- (low and high) income households that women who did not earn any income were found. In the middle-low income group a more conservative household strategy of having a sole earner was stronger. Although women earned fairly well in the upper-high income group, their income did not make a great difference to the wealth of their homes. Men earned sufficiently high incomes by themselves in this group. Overall, the significant participation of women in the labour market did not reflect an equally important contribution to the financial resources of the household: women's earnings were most important when hardship was greatest, but it made no significant impact on overall wealth levels within the best-off group.

The everyday routines of the women in the wealthier households (upper-low and upper-high income levels), which employ domestic labour, appeared fairly disengaged from their children's routines. Well-off mums' childcare activities involved taking to and picking up from school, feeding in the evening and putting into bed. Getting children out of bed, and feeding them breakfast and lunch was predominantly done by maids or nannies. In one of the homes the maid had to spoon-feed a pampered four-year old, but the mother did not count this among the household caring activities. Children in upper-low and upper-high households ordered maids to do things for them, and expected their whims to be fully attended to, or they would 'tell off' the maid. For a group of privileged children a culture of expectation of being serviced by a lower class person (usually, a woman) has been part of their growing up.

There are basically three ways in which women who do household work without pay can attempt to diminish their burden. One is by employing (or forcing) someone else to do the work, or some of it. Another is by putting pressure on the state for the provision of some public services to lessen this work. A third way is by deploying household technologies to facilitate the work. These three strategies can be combined. This paper considers the first and third, as the research found no evidence of housework burden issues being pressed upon governments either at a local or national level. However, I reflect about government intervention in domestic service in the conclusions.
1 I have not compared the maids' homes with those of their employers and I have not treated the three women interviewed who worked in domestic service as maids. They are classified as women in poor households for the purposes of this study. For access to the maids' voices regarding their occupation and family lives, see Brites (2001). 


\begin{tabular}{|c|c|c|c|c|c|c|}
\hline \multirow{2}{*}{ Technology } & \multicolumn{5}{|c|}{ Income } & \multirow{2}{*}{$\begin{array}{c}\text { total of } \\
\text { technology }\end{array}$} \\
\hline & low & middle low & middle high & upper low & upper high & \\
\hline cooker & 6 & $8 c$ & 6 & $8 c$ & 4 & 32 \\
\hline $\begin{array}{c}\text { microwave } \\
\text { oven }\end{array}$ & - & 4 & 5 & 7 & 4 & 20 \\
\hline fridge & 6 & 7 & 6 & 7 & 4 & 30 \\
\hline freezer & 1 & 7 & 4 & 7 & 4 & 23 \\
\hline dishwasher & 1 & - & 1 & 5 & 3 & 10 \\
\hline tar & 5 & 4 & 4 & & & 13 \\
\hline tumble dryer & - & 1 & 2 & 6 & - & 9 \\
\hline $\begin{array}{l}\text { Total of } \\
\text { families }\end{array}$ & 6 & 7 & 6 & 7 & 4 & 30 \\
\hline
\end{tabular}

Key: $\quad a=4$ washing machines owned by 'tanquinho' owners were used only for spinning. $\mathrm{b}=2$ old washing machines used for spinning only. $\mathrm{c}=2$ households ( 8 and 29 ) had 2 cookers.

Figure 1 Ownership of technology by household income level.

\section{machines}

Ownership of household technologies has increased sharply in Brazil. All the families I studied had cooker, fridge and washing machine or equivalent (see Figure 1). However, there were estimates that in the mid-1990s, only 75 per cent of Brazilian homes had both fridges and cookers (Abinee, 1994). These are universal household goods in countries such as Great Britain and the United States. The washing machine owned by $1 / 6$ of the families was of the most basic kind, called tanquinho. This is a $4 \mathrm{~kg}$ capacity washtub, which fills automatically with water, has a bleaching agent compartment, but no soap dispenser, and switches off automatically. It does not spin dry. Five of the six poorest families owned a tanquinho, while four more tanquinhos were owned by middle-low income households and another four by those of middle-high income. However, 
the two latter groups also owned older washing machines, which were used to spin dry clothes washed in the tanquinhos. Only the two upper-income groups did not own any tanquinho because they had access to better quality washing machines. Clearly the job of doing the laundry is more difficult with lower quality equipment. Wringing clothes by hand, or transferring from tanquinho to spin, increases labour considerably. But ownership of good quality technology did not necessarily mean ease of the household tasks of all concerned.

In two homes, two cookers were in use. In the Montes household the newer cooker had been a present from the man's mother. It was installed opposite the old cooker, which was used for frying and for making 'dirtier' or longer cooking foods. At the Oliveira's two kitchens were installed. A new fully fitted kitchen had been built and the old one had been transferred to an area of the 'service house', where the maid cooked. But the fridge had not yet been installed, and the maid needed to walk about 10 metres between the cooker, where she cooked in the 'service house', and the fridge, in the new kitchen inside the house. This had been her daily routine for six months. After washing up manually in the 'service house' (she was not allowed to use the dishwasher) the maid transported plates, pots and cutlery to the new kitchen where they were kept. The new kitchen was used only on weekends, by the woman of the house.

While this use of two kitchens is exceptional, it has a curious historical counterpart. In colonial times, when slavery prevailed, in the better-off homes, it was common to have two kitchens. The 'clean' kitchen was located inside the house, the 'dirty' kitchen outside. In the 'dirty' one, laborious sweets and desserts were cooked, and the heaviest and less hygienic tasks were carried out. One explanation for this spatial division of cooking activities has emphasized that, contrary to Europe, where the heat of the hearth provided cosiness, the Brazilian climate made the range cooker an object that was undesirable in the domestic space (Algranti, 1997). However, there are references that even in the very cold South proper cooking was done in small tents built in the backyards of houses (Saint-Hilaire, 1820-21), an explanation that may suggest that external kitchens aimed to provide a spatial separation that reflected the social divisions between masters and slaves (Lemos, 1989), which echoes maids and employers' relations nowadays. As Rita Oliveira says: 'I have built an outside kitchen for the maids to use because I got tired of having my kitchen scratched .... They [the maids] wrecked it all'.

The ways in which the performance of everyday domestic tasks is made easy or difficult, reflect unequal social divisions. For instance, it was accepted that electricity should not be used if it could be substituted by the labour of maids, and also it was widely perceived that maids could damage household technologies if they were allowed to use them. Many stories of damage, or of protective strategies by the mistresses, were told. 
'Washing up is included in her wages'. [Explaining why the maid did not use the dishwasher]. (...) 'The oven was self-cleaning, but she [the maid] used this chemical to remove dirt and corroded all the inside'. (Nina)

I'm afraid she [the maid]'Il break it. She does not pay attention to tasks [like using the dishwasher]. (Marcia)

'She does not know how to use it [the microwave oven] and she does not need to use it.' [Yet, this maid cooked everyday.] (...) 'The washing machine broke many times in the hands of the maid ... but if you don't have a washing machine no maid stays with you.' (Inês)

I've never told her [the maid] not to use it [the dishwasher]. But I think she doesn't know how to use it. (Eunice)

From a sociological and economical point of view the rationality of such practices rests on both the low labour cost of maids and the relatively high cost of electricity and technologies. Underlying these reasons there were also the lack of skills to operate machines due to low literacy, and the absence of training in the operation of technologies for those very persons who should in fact be their main users: the maids. The women employed to do housework in homes with everything (see Table 1 and Figure 1) were unable to make use of the equipment designed to make housework easier, better and more efficient. This technology was predominantly used on weekends, when access to the labour of servants was not available. The current use of labour is careless and wasteful because it is cheap and abundant. Training is not provided, tasks are not made easier. These practices are informed by the social morality prevailing in the country.

\section{morality}

How are people involved in, and how do they justify their practices, when they seem to be stuck in places of deep social differentiation?

I explored the 'ordinary morality' of domestic labour through the application of a vignette to participants in my study. My concern was with a particular morality or ethics of care. As defined by Tronto (1993), this refers to moral sentiments, not to reason. It is a morality of the daily experiences and moral problems of real people in their everyday lives. In practical terms, my method involved reading a vignette story to an interviewee, and asking their opinion about what the characters in the story should do. I applied four vignettes in this study. The moral reasoning portrayed by the one I present in this paper is mirrored in the other three, even though each of them addresses different dilemmas of everyday home life. I talked to each adult separately. 
The vignette explored here is a long one about a family's relationship with a maid. I used a method of building in a temporal dimension and altering the circumstances of the characters at a later stage. Respondents were invited to make a choice about what 'ought to' happen in the first, second and third stages. This increased the complexity of my story. The vignette story usually triggered the telling of further related stories about the respondents, their friends and families. The assumption built into this method is that meanings are social and that the choice of a particular action brings out both the personal and the public morality of relationships (Finch, 1987; Finch and Mason, 1993).

The story is a hypothetical situation based on real-life occurrences. The context is typical of Brazil and the language reflects relationships and taken-for-granted assumptions about the roles of individuals. For instance, to address a maid by Dona before her name is often a sign of respect indicating that she is older, but it can also carry an idea of affection or mark a social distance. A man who looks after his son with the assistance of a full-time living-in maid is clearly not doing it on his own. When the story says he does do so, it colludes with the invisibility of the maid's job. Respondents can either remark on this or agree with it.

Isabel and Sérgio had a 7-year old son, Pedro. They lived in a big and comfortable house. They both had full-time jobs and a maid, Dona Margarida, had been employed for 4 years. Dona Margarida looked after the house and Pedro, sending him daily to school; and she was an excellent cook. She lived in the house and had Saturdays and Sundays off. Isabel died suddenly and Sérgio had to look after Pedro on his own. Dona Margarida worked as before. Sérgio and Pedro never cleared the table, washed up, or made beds. They took a shower in the mornings and left their damp towels on the bathroom floor ... . It was always Dona Margarida who looked after everything. And now she looked after some of the things that Isabel used to do. Her work increased and she was tired. Do you think that Dona Margarida should:

- Ask Sérgio for a wage increase.

- Ask Sérgio to hire a helper for her.

- Leave the job.

- Ask Sérgio and Pedro to do some of the tasks that Isabel used to do before.

Respondents who were poor (in the two lowest income groups) tended to identify with the maid but feared that she should not leave the job, since jobs were difficult to find and the orphan boy was attached to her. Because she was clearly important to the family she should hint at a need for compensation for her increased effort. As a priority she should mention the need for a helper, but she should take what the boss would choose to give her: either help or wage. Betteroff respondents tended to emphasize the emotional attachment. More than half of the respondents (29) suggested that the maid should ask father and boy to do the tasks the late mother used to do, while nearly half of them (21) did not remark on the fact that Sérgio and Pedro created some new tasks for Dona 
Margarida. However, the well-off were more likely to suggest that father and son should do some of the tasks, while most low-income women said Dona Margarida should have a helper. Perhaps these women believed that the practical 'help' the maid could get from Sérgio and Pedro was not going to be very effective. Only one person, a (upper-high income) man, said the maid should leave the job.

Independently of the respondent's choice, I carried on with the vignette, unfolding the story.

Dona Margarida asked for nothing, and carried on doing her job and getting tired. One year later Sérgio got a girlfriend, Cléia, who came to live in the house. Dona Margarida's work increased because Cléia did the same as Sérgio and Pedro. And Cléia and Dona Margarida did not get on well. What do you think Dona Margarida should do?

- Ask Sérgio for a wage increase.

- Ask Sérgio to hire a helper for her.

- Leave the job.

- Ask Sérgio, Pedro and Cléia to collaborate by doing some tasks.

In this second episode, I presented the situation that unfolded one year later. This contradicted some respondents' previous opinions. I deliberately portrayed a maid of submissive character, in order to test the morality of the command submission relationship as my key concern was with how relations of inequality were perceived and dealt with in the home. This does not imply that servants in Brazilian homes are all submissive like Dona Margarida appears in this vignette. Indeed, many practices of resistance are also found, described by Jurema Brites (2001: 119-128) as subtle tactics of insubordination, which include 'borrowing' without permission clothes from employers and stealing food or objects.

In the vignette, the maid carried on as before, never making any demands or letting her boss know that she felt overburdened. The new girlfriend, living in the house, acted just like father and boy. The maid's work increased. I invited respondents to say what Dona Margarida should do, repeating the same alternatives as before. The gender dimension became relevant this time. The most common reply now, mostly by women, was that the maid should leave the job. This was because a potential substitute mother had emerged, changing the situation and creating conflict. Dona Margarida was then freer of the inputed emotional ties. Interestingly, unlike in the first situation, now those with higher income predominantly said that Dona Margarida should leave the job, underlining the gender dimension of care in which the girlfriend could substitute for the emotional labour of the maid, and confirming the caution of poorer respondents about losing a job.

I then carried the story further to a final episode in which the maid chose not to ask for anything but one year later lost her job due to growing conflict with the girlfriend. However, Dona Margarida found another job at a neighbouring house. Six months later Sérgio got in touch asking her to return: he had broken up with 
his girlfriend. I did not offer any alternatives as answers, but asked again: What do you think Dona Margarida should do? Some respondents thought she should now remain where she was, but more than half, in similar proportions by gender, thought she should return to the old job because of the emotional ties with the boy and his father.

She cannot abandon the child because she loves him. She should go back because of the boy - he's like a son .... But ask for a helper. (Maria)

She should go back because there was a friendship and this counts a lot. (Sandro)

In reality she helped bring up the child. She already had intimacy with the home. Return! (Cristina)

In a reversal of the pattern in the previous round, the suggestions that Dona Margarida should return to the old job predominated among those with higher income, while those with lower income tended to agree that the maid should not return to the old job. Resistance by the poor to being played off by the wealthy now surfaced. The fear of job loss no longer existed. But the richer felt the loss of care, and the emotional attachment by the maid was claimed back. Both submissive acceptance and resistance, as well as affective ties, are apparent in the reactions to this vignette, indicating a complex relationship between poverty and obedience, money and affect.

With the important exception of this last moment in the story, when the poorer would choose the maid not to return to the old job, this vignette shows that respondents' choices were consistent with a prevailing morality prescribing the dedication of the dispossessed to the well-off. This reflects what Teresa Sales (1994), in her study of Northeast Brazil referred to as 'the political culture of the gift'. It implies passivity and gratitude of the receiver in face of the giver and relates to a history in which slaves were dispensable, depending on the 'gift' of their superiors for their very survival. From this context, as remarked upon by various analysts (Kowarick, 1987; Lopes and Gottschalk, 1990), evolved a culture of social and political submission. Here the maid was not simply a worker but a devoted carer. However, the respondents' acceptance of men's detachment from housework and care did not equally apply to women. The late mother used to do some tasks like cleaning the table, washing up in the evening, or making beds and picking up damp towels from the bathroom. This shows that well-off women can effectively have hands on light housework despite the colonial ideal portrayed in contemporary soap operas of 'madams' avoidance of all physical work. The girlfriend too was expected to do these household tasks and not to behave like the father and the boy did. As illustrated by Regina's comments: 'She should return ... after so many years ... what prevented her was the girlfriend'. Resistance was mainly from the poor. Some remarked that Dona Margarida had been mistreated and that leaving damp towels on the floor was unacceptable. 
Some criticized Sérgio for treating her as a 'change of clothes', 'in and out', 'depending on having a girlfriend'. It was clear for some that Dona Margarida deserved much better treatment. Also, she was the ideal caring maid of many people's dreams, as shows Dércio: 'If there is affection for the family she should go back. I would like my maid to have an emotional link with the family, or at least with Naomi'. Naomi was his three-year old daughter, and Dércio had complained of his maid's lack of emotional attachment to her.

The pattern of gender relations in which most Brazilian domestic life is centred around the needs of men, where the woman services and the man provides, is socially pervasive, and it is the ideologically dominant pattern even when the woman is also a provider. In the vignette, or in accounts of real everyday life, triggered by the story of the vignette, it was not surprising that men did not do anything in the home. A particular sort of patriarchy supports these gender relations sustained by highly unequal relations of class, which affect inter-gender dynamics (Besse, 1996).

More specifically, deep social differences based on class and 'race' appear to contribute to a reduction of domestic conflict in relationships between women and men in well-off homes. Julia Souza (1980) was one of the first to point out the paradox that some Brazilian women's liberation came at the cost of the subordination of other women. She focused on the economic implications of this labour relationship for capitalist development, and also reflected on the inconsistencies of Brazilian feminism. Following on from this, Suely Kofes (1982), Sandra Azeredo (1989) and others have also argued that professional women may be able to progress in their careers because they can make use of the services of other women for domestic service. Moreover, Danielle Ardaillon (1989) has argued that the maid is the big problem of the professional woman: central to domestic life, their absence or disruption deeply affects the routine of the family, and Celma Vieira (1987) has emphasized the easier progress of white women in general at the expenses of black maids. Vieira has also observed how the living areas of maids in modern houses resemble the structure of colonial architecture that separated manor house and slave quarters. Although only a few families employ live-in maids, the little bedroom ('quartinho') and bathroom designed for maids are revealing of the status of domestic servants, either employed everyday or as occasional daily cleaners. As Donna Goldstein (2003: 80) describes, the toilet normally has no seat, the shower has no curtain and water dampens the whole room; the bedroom with a tiny bed is used to store all sorts of unwanted and disused items in the household.

At the end of the twentieth century, I still found evidence that the widespread use of domestic servants by the upper-and middle-classes had taken the edge off many conflicts about gendered domestic divisions of labour, since more menial domestic labour was given to poorer women. As reactions to the vignette 
showed, orders from middle-class men to lower-class women were perceived more strongly as 'a right' than the ordering to do that goes on between women.

This study has focused on the wealthier southeast of Brazil, but the social divisions between servants and better-off household members are even sharper in the North and Northeast regions. The value of domestic labour is lower, and the demands for care from the wealthy are greater, where poverty is higher. The price of Brazilian domestic labour increases considerably as one moves South and is highest in the big urban areas. But even in the economically affluent region of Greater Campinas, maids in middle-class households are rarely allowed to use all available household technologies. This is a consequence of the cheapness of domestic labour and it affects the patterns of development of household technologies. The good quality cookers and washing machines are very expensive, or imported, while the cheaper ones still demand considerable amounts of labour input for their operation (Silva, 1998). Although prices of technology have dropped over time, the cost of domestic labour has not increased sufficiently to make it attractive to replace maids with machines. The earnings by the poorer have not been sufficiently high to generate new waves of demand for technology in the home. In certain respects, this fits into the model of Brazilian society that some economists have called 'excluding modernity' (Miller, 1991). It has been based on income concentration and sophisticated consumption for a minority of the population, and exacerbates social differences. The fact that some betteroff women find that they need to have washing machines in order to keep their maids may be a small indicator of a trend towards less inequality.

\section{conclusions}

Reminiscing about the feminist debates in the 1970s in the United States, Barbara Ehrenreich (2002: 87) writes that '[t]he radical new idea was that housework was not only a relationship between a woman and a dusty bunny or an unmade bed: it also defined a relationship between human beings, typically husbands and wives'. She goes on to say that talking about housework was to talk about power. The degradation of housework was not derived from it being manual labour, but from the fact of the person who is cleaned up after being consistently male, while the person who cleans up is consistently female, rendering housework as a 'symbolic enactment of gender relations' (p. 88). Analysing the contemporary servant economy, Ehrenreich remarks that '[i]ncreasingly often, the house cleaner is a woman of color and a recent arrival from the Third World' (p. 102), bringing about the challenge of making this work visible again. She argues that ' $[\mathrm{t}]$ he growing servant economy .... is largely a result of men's continuing abdication from their domestic responsibilities' (p. 103). However, housework is not, the same sort of work that it was. The current context in developed countries is permeated by an array of machines, 
services and 'nearly ready products' (from cooking to clothing and cleaning) as part of a new 'technological nexus' (Silva, 2002) enabling a lifestyle less dependent on long domestic labour hours. Care of children and of other persons, and some household tasks do remain essential for quality daily living, but the context is different from that of the 1970s.

In Brazil, however, continuities are stronger. Of course, a lot of feminist ideas have been debated in Brazil and many have been productive in bettering women's social stand. However, not much has yet affected domestic relations. Women's paid jobs growth has not changed the patterns of domestic living much and homes keep on being run by women in paid and unpaid arrangements. Gender relations in well-off homes are generally not perceived as requiring change. The tensions are deflected onto a lower-class woman, normally with darker skin. The ability to cushion gender conflicts in this way has buffered challenges to traditional gender patterns. It has also affected technological developments as demands for lessening housework chores are not immediately pressing.

Recent governmental interventions in the regulation of domestic service is likely to impress changes both on gender relations and technological innovations in the home, as well as in improving conditions for workers. In 2006 only 28 per cent of domestic workers had formal employment. Yet, official measures and sanctions had increased formalization by 4.6 per cent between 2004 and 2006, demonstrating the effects of regulation (ILO, 2008). The Federal Constitution of 1988 promulgated after the military regime (1964-1985) granted new rights to domestic workers and allowed the formation of trade unions, increasing social protection. This is the context enabling informal employment to decrease. The Unions, however, as argues Dominique Vidal (2008), were turned from social assistance to judicial actors without being given the means to effectively intervene in the field and have struggled to take assertive political action. Their success lies in spreading a sense of fairness, knowledge of legal rights among working-class women and awareness of the law.

Two different scenarios demand reflection from the case explored in this paper. In one, Brazilian domestic service dwindles like it did in the UK in the 1930s (Glucksmann, 1990) and in the US after the Second World War (Thistle, 2006). Would greater equality in the home and increasing modernization of household technology ensue? In the other, the current increasing use of immigrant women's domestic labour in Europe and the USA may come to affect the machines for housework and morality of everyday living in the home, slowing the pace of changes in gender relations. The challenges for feminist thinking posed by both scenarios are pressing. 


\section{acknowledgements}

The study in 1997 was funded by the University of Campinas and CAPES, in Brazil. I thank Patricia Pinho for her invaluable research assistance at that time. In 2008, I revisited this study with Dr Pinho, while she held a British Academy Visiting Fellowship at the Open University.

\section{author biography}

Elizabeth B. Silva is a professor of Sociology at the Open University. Her current research on 'technology and personal lives' engages with gender, family practices and the material as everyday concerns. This has been developed concomitantly with an investigation of 'cultural capital and social exclusion', which has a particular focus on personal interdependencies of cultural consumption in households. Her empirical research has involved the integration of a variety of research methods and it has been strongly informed by cross-national and cross-cultural comparisons.

\section{references}

Abinee (1994 and 2005) A Indústria de Eletrodomésticos no Brasil: informações consolidadas, São Paulo: Abinee.

Algranti, L. (1997) 'Famílias e Vida Doméstica' in Souza, L. (1997) editor, História da Vida Privada no Brasil, São Paulo: Compania das Letras, 83-154.

Anderson, B. (2000) Doing the Dirty Work. The Global Politics of Domestic Labour, London: Zed Books.

Ardaillon, D. (1989) o Cotidiano de Mulheres Profissionais: 0 Engodo do Individualismo, Ph.D. Thesis, Universidade de São Paulo.

Azeredo, S. (1989) 'Relações entre Empregadas e Patroas: Reflexões sobre o feminismo em países multiraciais' in Costa, A. and Bruschini, C. (1989) editors, Rebeldia e Submissão, São Paulo: Editora Vértice/Fundação Carlos Chagas.

Besse, S. (1996) Restructuring Patriarchy. The Modernization of Gender Inequality in Brazil, 1914-1940, Chapel Hill: University of North Carolina Press.

Brites, J. (2001) Afeto, Desigualdade e Rebeldia: bastidores do serviço doméstico, Ph.D. Thesis, Porto Alegre: UFRGS.

Bruschini, C. (2000) 'Gênero e Trabalho no Brasil: Novas conquistas ou persistência da discriminação? (Brasil, 1985/1995)' in da Rocha, M. I. B (2000) editor, Trabalho e Gênero, São Paulo: Editora 34.

Bruschini, C. (2007) 'Trabalho e genero no Brasil nos ultimos dez anos' in Hirata, H. (2007) editor, Marché du Travail et genre: comparaisons internationales Brésil-France, Paris: MAGE, CNRS.

Ehrenreich, B. (2002) 'Maid to order' in Ehrenreich, B. and Hochschild, A. (2002) editors, Global Woman: Nannies, Maids and Sex Workers in the New Economy, London: Granta Books, 83-103.

Ehrenreich, B. and Hochschild, A. (2002) (editors) Global Woman: Nannies, Maids and Sex Workers in the New Economy, London: Granta Books.

EJWS (2007) European Journal of Women's Studies, Special issue on 'Domestic Work', Vol. 14, No. 3, 187-296.

Finch, J. (1987) 'Research note: the vignette technique in survey research' Sociology, Vol. 21, No. 1: 105-114. 
Finch, J. and Mason, J. (1993) Negotiating Family Responsibilities, London: Routledge.

Gitahy, L., Araujo, A.M.C., Alessandra, R., da Cunha, A.M. (1997) 'Relações Interfirmas e gestão de recursos humanos na cadeia produtiva de linha branca' Relatório de Pesquisa, FINEP/CEDES/ $\mathrm{CNPq} /$ Unicamp.

Glucksmann, M. (1990) Women Assemble, London: Routledge.

Goldenstein, D. (2003) The Aesthetics of Domination. Class, Culture and the Lives of Domestic Workers' in Laughter out of Place, Berkeley: University of California Press.

Hochschild, A. (1997) The Time Bind, New York: Metropolitan Books.

ILO (2005) 'Trabalho Doméstico e Igualdade de Gênero e Raça: desafios para promover o Trabalho Decente no Brasil' OIT, Brasil, downloaded March 13, 2008, http://www.sei.ba.gov.br/ conjuntura/ped/datas_comemorativas/pdf/emprego_domestico_2005.pdf.

ILO (2008) 'Mais trabalho decente pra trabalhadoras e trabalhadores domésticos no Brasil' downloaded January 6, 2009, www.oit.org.br/download/trabalho_domestico_25_04_2008.pdf.

Kofes, S. (1982) 'Entre nós Mulheres, Elas as Patroas e Elas as Empregadas' in Arantes, A.A., Feldmann-Bianco, B., Brandao, C.R., Correa, M., Slenes, R., Kofes, S. and Stolcke, V. (1982) editors, Colcha de Retalhos. Estudos sobre a Família no Brasil, São Paulo: Ed Brasiliense, 183-193.

Kowarick, L. (1987) Trabalho e Vadiagem, São Paulo: Ed. Brasiliense.

Lemos, C. (1989) História da Casa Brasileira, São Paulo: Contexto.

Lopes, J.R. and Gottschalk, A. (1990) 'Recessão, Pobreza e Família - A década pior do que perdida' São Paulo em Perspectiva, Vol. 4, No. 1.

Miller, L. (1991) Pobreza e Distribuição de renda no Brasil: a década de 80, Rio de Janeiro: IBGE.

Neto, B. (1992) A indústria de eletrodomésticos de linha branca: tendências internacionais e situação no Brasil, Relatório de Pesquisa, Campinas: Instituto de Economia, UNICAMP.

PNAD (2001) Pesquisa Nacional por Amostra de Domicílios, Rio de Janeiro: FIBGE.

Saint-Hilaire, A. (1820-21 [1974]) Viagem ao Rio Grande do Sul, São Paulo: Edusp.

Sales, T. (1994) 'Raízes da desigualdade social na cultura política brasileira' in Revista Brasileira de Ciências Sociais, Vol. 25, São Paulo: ANPOCS, 26-37.

Sarti, C. (1996) A Familia Como Espelho. Um estudo sobre a moral dos pobres, Campinas: Fapesp/ Ed. Autores Associados.

SEADE (2002) 'O Mercado de Trabalho Feminino na Região Metropolitana de São Paulo' Mulher e Trabalho, 7, March.

Silva, ع.B. (1998) 'Tecnologia e Vida Doméstica nos Lares' Cadernos Pagu, Vol. 10: 21-52.

Silva, ع.B. (2002) 'Time and emotion in studies of household technologies' Work, Employment, and Society, Vol. 16, No. 2: 329-340.

Souza, J. (1980) 'Paid domestic service in Brazil' Latin American Perspectives, Vol. 24, No. VII (1): 35-63.

Thistle, S. (2006) From Marriage to the Market, Berkeley: University of California Press.

Toledo, J.C. (1989) Para um levantamento dos impactos sócio-econômicos da automação microeletrônica: Indústrias de Formas - 'Linha Branca', Relatório de Pesquisa, São Paulo: DIEESE/ FINEP.

Tronto, J. (1993) Moral Boundaries. A Political Argument for an Ethic of Care, New York: Routledge.

Vidal, D. (2008) 'Emerging from dependence: domestic employees' trade unions in Brazil' in La vie des Idées, retrieved 06-01-2009, http://www.laviedesidees.fr/Emerging-fromDependence-Domestic.html.

Vieira, C.R. (1987) 'Negra: Mulher e doméstica - Considerações sobre as relações sociais no emprego doméstico' Estudos Afro-Asiáticos, Vol. 14: 141-158.

doi: $10.1057 /$ fr. 2009.37 